\title{
A Study of STEAM Model Development and Assessment Method for Deep Learning: Through the Voice of Mimesis and Brontë*
}

\author{
Lee, Kwang-Soon ${ }^{1}$
}

\begin{abstract}
This research aimed to explore a humanities-based STEAM (H-STEAM) model for EFL undergraduates $(n=72)$ to improve deeper thoughts and language proficiency in a multidisciplinary setting. The H-STEAM focused on the integration of a literature text, Emily Brontë's Wuthering Heights, and the philosophical analysis framework of mimesis as a humanities resource. For a specific teaching and learning method, various group activities based on project-based learning (PBL) were fabricated to enhance collaborative and conceptual learning both inside and outside of the classroom. Analyzing the relationship of Wuthering Heights and mimesis, learners shared and adopted peers' opinions with openness. They could improve problem-solving ability, caring, communication skills, and selfreviewing practice when accumulating content knowledge and generating creative ideas. This study organized student-based assessment; self-assessment (SA) and peer-assessment (PA). SPSS 25 was conducted for the correlation and reliability analysis of SA and PA, and the evaluation of linguistic improvement. The results indicate that the H-STEAM facilitating PBL can be more workable through openness and community caring. The integration of collaborative and conceptual learning through PBL can empower learners' autonomy and produce deeper thoughts, which can contribute to deep learning. Consequently, this study may suggest a path to develop H-STEAM for higher education.
\end{abstract}

Keywords: humanities-based STEAM (H-STEAM), project-based learning (PBL), Emily Brontë's Wuthering Heights, mimesis, self-assessment (SA), peer-assessment (PA)

Applicable levels: secondary, higher education

\footnotetext{
* This work was supported by the Ministry of Education of the Republic of Korea and the National Research Foundation of Korea. (NRF-No. 2017S1A5A8022929)

${ }^{1}$ Corresponding author, Lecturer, Dept. of English Language and Literature, Mokpo National University, 61, Dorim-ri, Cheonggye-Myeon, Muan-Gun, Jeonnam, 534-729, Korea (E-mail: leesue67@yahoo.com)

Received: October 6, 2021

Revised: November 14, 2021

Accepted: November 21, 2021

Copyright: (C 2021 The Society for Teaching English through Media (STEM)

This is an open access article distributed under the terms of the Creative Commons Attribution Non-Commercial License (http://creativecommons.org/licenses/by-nc/4.0), which permits unrestricted non-commercial use, distribution, and reproduction in any medium, provided the original work is properly cited.
} 


\section{INTRODUCTION}

The tide of the $21^{\text {st }}$ century requires the way to increase infinity and create productive knowledge by connecting learning contents with real world life. For this, it focuses on the development of STEAM which creates a venue where learners can break down the borders between learning departments and share knowledge. With this trend, the educational values of STEAM in the classrooms have been studied gradually. Originally, STEAM conjugates education, psychology, philosophy, language, music, and arts along with STEM which consists of Science, Technology, Engineering and Math. To accomplish 'convergence education', STEAM education avoids a superficial understanding of course materials and supports a reasonable solution through critical analysis about social issues. At the same time, as it stresses 'holistic education' which covers learners' comprehensive understanding of natural, humanistic and global aspects, STEAM needs 'creative design' and 'emotional touch'. Consequently, its core competencies can be summarized as $4 \mathrm{Cs}$ of creativity, communication, convergence and caring (Baek et al., 2012). They reflect the need of cultivating the new generation with self-direction and creative problem-solving ability by stimulating humanistic imagination and artistic creativity in the rapid change of society and technology. In fact, according to the U.S. Bureau of Labor Statistics, STEM and STEAM related jobs are projected to grow by $8 \%$ with an average wage of $\$ 86,980$ from now to 2029 , while the other occupations will grow by $3.4 \%$ with an average wage of $\$ 39,810$ (Lathan, 2021). In addition to this economic value, by promoting interdisciplinary and cross-curricular learning, STEAM can contribute to deep learning that connects previous knowledge and new one, generates deep understanding on different courses, and helps learners think critically (Warburton, 2003).

With this, the Ministry of Education, Science and Technology in South Korea has encouraged STEAM in schools since 2011 (Kwon, Park, \& Lee, 2009). Although many of STEAM studies have been tried in science and technology departments such as the development of STEAM textbook on measuring water pollution with indicator organisms (Hong, Hwang, \& Choi, 2012), current studies are being conducted in various fields. For instance, Lee (2015) designed geography-centered STEAM by converging a social science subject, geography, with arts curriculum and physical science under the title, how to build a renewable energy power plant in our town. Art-focused STEAM was explored to verify emotional touch in art class through the 6 factors of interest, immersion, achievement, new challenge, practice and caring (Kang, Lee, \& Lee, 2014). The research shows that the process of emotional touch in STEAM evolves from an individual aspect to the relation with other people or communities and even to the relation of nature and culture. Recent studies also shed new light on the significance of humanities in the frame of STEAM as humanities can awaken learners' consciousness from values to cultures while drawing learners' interest in human affairs as well as foster learners' critical thinking and communication skills (Bourdeau \& Wood, 2021). For example, an integrated humanities medical curriculum (IMHC) emphasized the life cycle of patients and the scope of the society to which they belong (Kim et al., 2015). Further, Cho (2018) explored the H-STEAM Middle School Free Semester Program by incorporating the critical competences of both humanities and STEAM. It was developed for creativity and career aptitude.

However, most of the STEAM studies were targeted for middle school students in the free-semester system, high or elementary school students. Generally, $27.1 \%(n=3,127)$ of all the elementary, middle, and high schools were assumed to carry out STEAM in 2015 (Park, Byun, Sim, Baek, \& Jeong, 2016). Although STEAM such as a convergence class of literature and theatrical performance using Shakespeare's Hamlet (2008) and Martyn Ford's Five Short Plays (2008) was tried as liberal education to cultivate learners' humanity (Choi \& Lee, 2016), it has rarely been developed for undergraduates. Moreover, the studies on humanities-based STEAM (H-STEAM) conjugating literature and philosophy in English education are rarely conducted in both domestic and international research. In this regard, Cho (2018) pointed out the problem of Korean H-STEAM that there is no true integration of humanities except the cases of using liberal arts simply as an incidental device to teach science and technology in an interesting way. As a result, as there are not many empirical reports about H-STEAM in English education, various studies on H-STEAM are required. In this study, as the primary resource of content-knowledge integration to dissolve language, literature and philosophy, Wuthering Heights (Brontë, 1996) was analyzed in the perspective of mimesis, which means the representation of real-world. As the reason,the symbolic meaning of literary language in literature and philosophy can help readers rebuild reality through interpretation, which is called the stages of mimesis by Ricoeur (David, 1991). For the H-STEAM design, this study also adopted Miller's (2014) argument that PBL with a student-based assessment 
is the best tool to make STEAM successful. Current research questions are as follows.

1. What effect does humanities-based STEAM learning have on EFL learners' language performance?

2. What effect does humanities-based STEAM learning have on project-based learning focusing on selfassessment and peer assessment?

\section{LITERATURE REVIEW}

\section{The Significance of Humanities-Based STEAM (H-STEAM) Learning}

\section{1) The Understanding of H-STEAM as an Impetus of Deep Learning}

To induce the relation between H-STEAM and deep learning, we need to understand what deep learning is and what the educational role of H-STEAM is in an EFL setting. Despite subtle differences in its definition, it is generally accepted that deep learning comes from learners' deep understanding of learning materials and enhances learners' autonomy by making learners curious, independent, thoughtful, and active (Huberman, Bitter, Anthony, \& O'Day, 2014). However, deep learning cannot take place naturally. As deep learning essentially needs a learning environment to develop students' critical thinking and problem-solving ability, it should be designed systematically for deeper thoughts (Gu, 2021). For that, Jensen and Nickelsen (2008) suggested two strategies. First, it should be considered to create learners' community requiring learners' cooperation to solve problems, as passive learners can be active through inquiry in groups. Second, with activating and evaluating learners' previous knowledge, the process of forming, transferring, and applying new knowledge to a real world should be followed.

Fortunately, the learning environment to promote deep learning strategies can be formulated in a STEAM program. For the reasons, first, STEAM contains the connection across disciplines, discovery, and problem-solving effort (Hillyard, 2021). Second, learners who experienced STEAM could change their extrinsic motivation into intrinsic motivation, which could lead to long-term learning and deep learning (Salmia, Thuneberga, \& Bogner, 2020). Third, STEAM can generate a platform to achieve the deeper learning out-of-school environments (Schmid \& Bogner, 2015). These studies support the educational value that STEAM facilitating humanities with authentic context can clarify the abstract concepts and cause learners to experience real-world issues.

\section{2) The Educational Role of Humanities in H-STEAM}

The objectives of deep learning above can be aligned with the educational potentials of humanities in H-STEAM. First, the convergence of linguistic learning and humanistic education can be enhanced. Language in an EFL setting is a tool to converse users' ideas or thoughts as well as a vehicle for learners to experience the economic, cultural, and historical issues of a society (Hillyard, 2021). While using literary texts, the infiltration of humanistic education can take place naturally in the classrooms with the activities of listening, reading, speaking, and writing. In addition, when teachers' scaffolding is planned well for context and creative design, the humanistic elements such as history, philosophy, language arts and culture through literary works, films, or theme-based debate can cultivate learners' indepth knowledge (Cho, 2018). Particularly, for convenience and accessibility, literary texts can be used in the virtual space of SNSs (social network services) such as Facebook, Twitter, Line, or KakaoTalk. It can promote learners' participation and their language perception ability because the citizens of the $21^{\text {st }}$ century are naturally familiar with SNSs like SNS aborigines (Huberman et al., 2014). In fact, it is supported through the review of more than 350 studies that a technology-assisted environment using learners' individual devices including computers and mobiles can enhance learners' pronunciation training and interaction in foreign language learning. The environment can activate the acquisition of meta-linguistic knowledge referred to as the ability to correct or explain a second language (Golonka, Bowles, Frank, Richardson, \& Freynik, 2014). Baker (2017) also supported the impact of facilitating mobiles on language outcomes as learners can experience various voices. Learners can experience the reduction of workload by selecting words and incorporating sentences through the touchscreen (Kim \& Schatschneider, 2017). 
However, too much emphasis on practicing language skill can reduce learners' deeper thoughts and hinder the development of their analyzing or critical thinking ability, although learners can show their fluent pronunciation and elaborated language $(\mathrm{Gu}, 2021)$. Therefore, it is necessary that language education should be involved in improving learners' thinking process as well as language use according to learner's level.

Next, humanities can enhance communication skills and convergence that the $4^{\text {th }}$ industrial revolution requires (Pastreich, 2018). As the reason, the humanistic elements combined with visual and audio resources such as films can activate visual thinking skills. Although thinking through verbal language generally can be considered as to be analytic and logical, verbal thinking has an inseparable relation with visual thinking and plays a key role as an active problem-solving process (Brumberger, 2007). While analyzing visual resources, learners can be involved in learning naturally (Matrix \& Hodson, 2014). Their experience through hands-on, practical caring and creative activity contributes to developing a self-directed learning environment and thinking creatively as emotional touch. For instance, creating and demonstrating a learner-centric digital storytelling in the target language can develop learners' communication skills and build up empathy between speakers and listeners (Housen, 2002). In the aspect of linguistic development, a digital storytelling-facilitated interdisciplinary curriculum improved speakers' English proficiency and creative thinking skills (Yang, Chen, \& Hung, 2020). Collaborative digital storytelling also improved writing (Tanrıkulu, 2020). The finding implicates the usefulness of technology-combined humanities. In this regard, this study noticed an H-STEAM framework that can contain a learner-centric digital storytelling as a group project. Consequently, H-STEAM can help embody the learning objectives of discovery, integration, collaboration, deeper thoughts, problem-solving, critical thinking, creativity, and autonomy which deep learning implicates. For the infusion of these elements, the humanistic resources of a literary work and a philosophical framework were converged.

\section{The Background Selecting Mimesis and Wuthering Heights for H-STEAM}

As students can experience artistic and scientific structure analysis, or relation analysis between characters in films, YouTube series and literature, a humanities-focused model can generate a venue for students to acquire critical thinking skills and creativity. For instance, Bourdeau and Wood (2021) developed humanities-focused modules, each of which had short videos. One model was composed of "The Starry Night" (Vincent Van Gogh's work, 1889), a photograph of the Milky Way and an orchestral suite. There were also other modules combining Walt Whitman's poem, When I Heard the Learn'd Astronomer (1865), Frankenstein (Shelly, 1818) and several movies including Interstellar (Nolan, 2014), The Martian (Scott, 2015) and The Matrix (Wachowski \& Wachowski, 1999). In this experiment, learners generated various interpretations of the same model, searching for relevant information.

Similarly, in the aspect of the connection of image creation, interpretation, and rational analysis (David, 1991), the academic grounds of combining mimesis and Wuthering Height can be found. Firstly, literary works have mimetic elements to reflect social and economic problems as well as human nature and the presentation of narrators (McCaffery, 2008). Learners can assume a role in real-world scenarios while analyzing the works. As the scenarios can reflect the complexity and ambiguity of real-world challenges, the authentic complex situation may cause learners to apply 'what they learned' to a real-world (Coombs, 2012). For example, through the social background of Wuthering Heights, learners can understand how the hierarchy based on a traditional agricultural society collapsed when facing industrial revolution. Further, they can figure out how upward mobility to a higher social or economic position and the collapse of wealth caused cultural change (Ferns, 2003). Accordingly, Wuthering Heights can be the main resource to cultivate learners' creativity and critical thinking by digging learners' involvement through group discussion and experiencing collaborative learning as a team project. Secondly, rethinking the literary works through mimesis, which is referred to as a term of literary criticism and philosophy, can provide learners with critical perspectives by distinguishing similarities from differences, and by seizing their hidden meanings. As mimesis integrates a philosophical, cross-cultural and psychological thought with an aesthetic perspective, it can be used for a holistic education-based teaching and learning model. Thirdly, learners can experience higher-order thinking requiring critical thinking, analytic reasoning and problem-solving. For example, the analysis on the relationship of 'civilization \& nature', 'center \& margin', 'desire \& revenge', and 'self \& other' 
including the relationship between 'urban and rurality' in Wuthering Heights (Stoneman, 1998) could be explored in the perspective of mimesis. Therefore, students can be productive learners while exploring problems and finding a solution through authentic performance.

\section{The Infiltration of Project-Based Learning (PBL) to H-STEAM}

Hillyard (2021) argues that the good way to integrate STEAM in a language class is the connection of STEAM with 'language', 'literature', or 'project-based learning (PBL)'. Above all, she emphasizes PBL as a critical method to acquire problem-solving ability in that PBL can generate the problems which students must solve. PBL has advantages to make H-STEAM successful in the following four aspects. Firstly, PBL can be an accelerator of involvement. Assigning a project can draw learners' participation and help learners demonstrate how much they understand content-knowledge (Miller, 2014; Polman, 2000). As learners' motivation and engagement affect deep learning (Warburton, 2003), the fusion of PBL in an H-STEAM program can promote learners' deep learning. Secondly, PBL can contribute to 'self-directed learning'. PBL includes challenging tasks of understanding a learning goal, designing ideas, and engaging in problem-solving activities. So, while solving the tasks, learners can find other additional examples and the inter-correlation between issues. They can raise their consciousness on learning materials and promote knowledge growth. Thirdly, PBL can create collaboration between peers and a learning community where inquiry, peers' feedback and sharing ideas are guaranteed. The process will lead to new knowledge and deeper thoughts (Hillyard, 2021). Fourthly, with PBL, learners can experience the four steps of creativity; (a) generating ideas, (b) digging deeper into ideas, (c) openness and courage to explore ideas, (d) listening to learners' own inner voice (Treffinger, Young, Selby, \& Shepardson, 2002). With creative outcomes, learners can participate actively in learning (Kolmos \& Holgard, 2007). Consequently, the use of PBL can be projected to elaborate the process of HSTEAM.

In PBL-based classrooms, learners can evaluate their own learning attitude and achievement, as well as their teams' achievement. First, in collaboration-centric problem-solving activities, as it is crucial to engage every individual in a team project, a team project requires 'peer assessment' focusing on process-centric evaluation rather than productcentric evaluation to prevent 'the free-rider effect'. It enhances learners' meta-cognition by raising learners' responsibility and offering an opportunity to self-review. So, peer assessment can be an optimal indicator for the success of long-term learning (Liu, Lin, \& Yuan, 2002). In fact, learners can evaluate peers' contribution to managerial, procedural, and social parts which an instructor cannot recognize easily, despite the concern that learners cannot evaluate as appropriately as instructors (Lee \& Lim, 2012). Then, while self-reviewing their attitudes, learners can adjust and develop their ideas regardless of accepting new knowledge, which can enhance inner cognition (Cress \& Kimmerle, 2008). Last, as students' self-assessment can provide an educator with the opportunity to incorporate students' experience into his or her teaching method (Macdonald, 2008), it also can develop the way of teaching. Consequently, student-based assessment in PBL can be a form of important learning (Alias, Masek, \& Md Salleh, 2015; Kolmos \& Holgard, 2007). A deep learning-oriented H-STEAM model can be described as Figure 1.

\section{FIGURE 1}

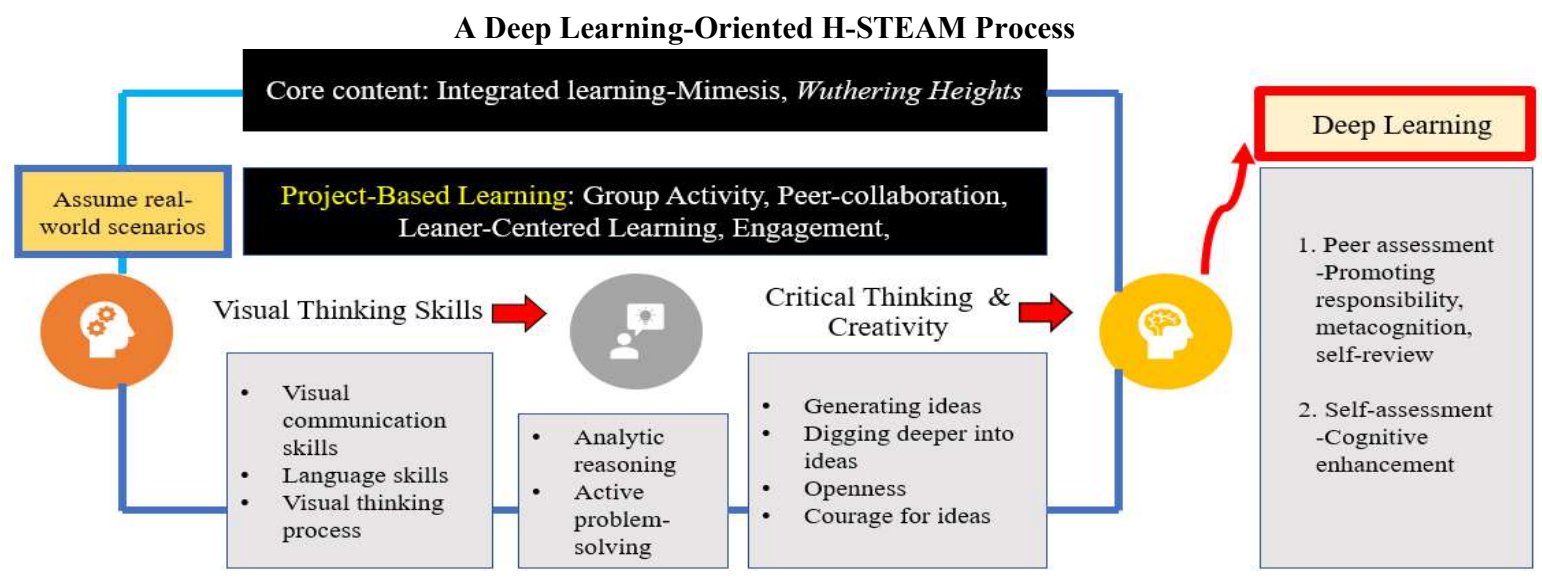




\section{METHODOLOGY}

\section{Participants}

72 Korean undergraduates (female; $n=30,42 \%$, male; $n=42,58 \%$ ) took an English conversation class as a liberal art in a university, Jeolla Province, South Korea. During the course, they experienced H-STEAM facilitating the convergence of Wuthering Heights and the philosophical frame of mimesis for one semester (the class time: 3 hours a week). In the first semester (March through June) of Academic year 2019, the experiment was conducted for 12 weeks except a mid-term and a final-term test period. The class consisted of 65 juniors, 4 sophomores, and 3 seniors. Their academic departments were various: Business Administration $(n=13)$, Education $(n=5)$, Engineering $(n=4)$, Humanities $(n=17)$, Human Ecology, Music and Fine Arts and Physical Education $(n=2)$, Social Science $(n=6)$, and Natural Science $(n=25)$. They all had no experience visiting foreign countries to participate in a student exchange program. Judging from TOEIC score (500-600 points, $M=560.58$ ) which they submitted at the beginning of the semester, it was confirmed that their language performance levels were similar. They had basic knowledge about grammar, vocabulary, and sentence structure to deliver their opinions in daily conversation. However, as they had difficulty in complex situations, they needed to be exposed to various English expressions in the real world.

\section{Research Instrument}

\section{1) Data Collection and Analysis}

First, 72 participants took a pre-test and a post-test which consisted of 30 multiple-choice questions. They were based on the acquisition of collocational knowledge. For that, the frequency of the words in the script of a film adaptation of Wuthering Heights was analyzed through AntConc. 3.2.4. The most frequently used verbs of Token Types were selected for the collocation-related questions. The reasons to select collocation-based testing were as follows: (a) Considering that vocabulary, grammar, and the appropriate use of language are fabricated in a dialogue (Sinclair, 2004), collocational knowledge can help learners understand the fixed patterns which are natural to native English speakers. (b) As the collocation of phrasal verb or verb and noun is more used in an everyday conversation informally than a word with same meaning (Cornell, 1985), learners can recognize the patterns naturally through the movie. In addition, the H-STEAM frame integrating movies, YouTube, and a literary work was expected to expose the participants to various collocation.

Second, a post-survey was conducted to assess the efficacy of PBL in H-STEAM. It was made up of self-assessment (SA, 6 items) and peer-assessment (PA, 7 items). All the questions except the three open-ended ones on the experience of the H-STEAM were based on a 5-Likert scale: $\mathrm{SA}=$ strongly agree, 5; $\mathrm{A}=$ agree, $4 ; \mathrm{N}=$ neutral, $3 ; \mathrm{D}=$ disagree, 2; $\mathrm{SD}=$ strongly disagree, 1 (see Appendix 1). The items of SA and PA reflect the aspects of deep learning: SA: involvement, generating ideas, responsibility, openness, caring, and self-direction; PA: creative outcomes, completing role-assignment \& satisfaction, creating academic mindsets, conceptual knowledge, community caring, sympathy \& harmony, and communication \& collaboration skills. All the collected data were analyzed by SPSS 25 version: With descriptive statistics, a paired $t$-test and a one-way ANOVA were run on the tests while correlation and reliability analysis were employed for the post-survey.

\section{2) Validity and Reliability of Post-Survey}

Table 1 and Table 2 verify the strong reliability (SA: $\alpha=.856$, PA: $\alpha=.894$ ) and high inter-consistency. The range of skewness (SA: $-1.101 \sim 0.044$, PA: $-.953 \sim-.091$ ) and kurtosis (SA: $-1.057 \sim 1.643$, PA: $-.946 \sim-.200$ ) supports the normality of SA and PA. Figure 2 also describes the normality of the overall distribution of SA (M: 4.183, SD: $0.642)$ and PA ( $M: 3.976, S D: 0.714)$ with the number of students on each bar. Consequently, all the variables of the post-survey can be dependable statistically. 
TABLE 1

The Reliability and Inter-Consistency of SA

\begin{tabular}{ccccc}
\hline Content & Corrected item-Total Correlation & Cronbach's Alpha if item deleted & Skewness & Kurtosis \\
\hline SA1 & .668 & .827 & -.609 & -.650 \\
SA2 & .700 & .821 & -.349 & -.623 \\
SA3 & .783 & .805 & -1.101 & 1.643 \\
SA4 & .662 & .829 & -.881 & .049 \\
SA5 & .580 & .847 & -1.018 & .465 \\
SA6 & .498 & .856 & .044 & -1.057 \\
\hline \multicolumn{5}{c}{} \\
\hline
\end{tabular}

TABLE 2

The Reliability and Inter-Consistency of PA

\begin{tabular}{ccccc}
\hline Content & Corrected item-Total Correlation & Cronbach's Alpha if item deleted & Skewness & Kurtosis \\
\hline PA1 & .704 & .877 & -.665 & -.467 \\
PA2 & .784 & .867 & -.648 & -.521 \\
PA3 & .782 & .867 & -.953 & .590 \\
PA4 & .760 & .871 & -.730 & -.200 \\
PA5 & .656 & .883 & -.492 & -.587 \\
PA6 & .629 & .886 & -.178 & -.946 \\
PA7 & .547 & .895 & -.091 & -.813 \\
\hline \multicolumn{5}{c}{} \\
\hline
\end{tabular}

FIGURE 2

Normality of SA and PA
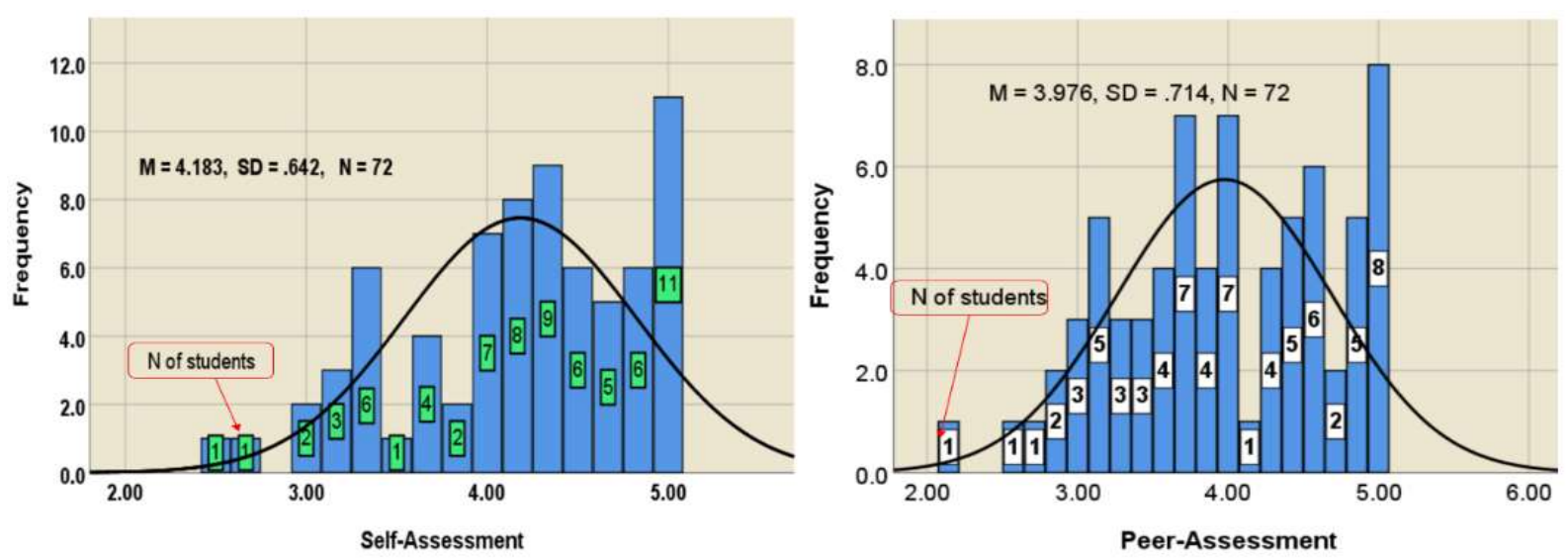

\section{An H-STEAM Model Design and Characteristics}

\section{1) The Development of H-STEAM}

The course design of H-STEAM was composed of the following four steps. As a step 1, the participants $(n=72)$ were grouped into 12 teams, each of which consisted of 6 members. They were assigned time to guess the story in class. They were made to watch YouTube of Wuthering Heights (Movieclips Coming Soon, 2012) without subtitles and write down their own feelings and ideas (e.g., what is happening? what is the topic? or what is the relationship between the couple?) on the story without being informed of it. The activity was expected to promote their creativity by generating ideas, which can lead to the openness to explore new ideas (Treffinger et al., 2002) and to help them to compare their first feeling with the real storyline of the movie. Next, the participants were provided with information such as the definition and the visual description of mimesis with visual materials showing a tribal decoration (Silvester, 2009) and an architecture design (Lienhard, n.d.) 
As a step 2, various activities were facilitated in class. First, learners' comprehension was promoted by multimediabased sources. The students were provided with YouTube (Angel, 2016) implicating the detailed themes of Wuthering Heights and a story summary to Kate Bush's song (Bronte, 2010) with an electronic plot summary (Price, 1996). They also appreciated the two film adaptations of Wuthering Heights, which were directed by Kosminsky (1992) and Arnold (2011). Second, after recognizing the storyline, learners participated in the activities such as describing the specific scene on a cartoon paper in English and interpreting the characters' lines of the film adaptations in Korean. Third, they tried to find mimesis of the scenes under the specific categories: Time and mimesis, Events and mimesis, Characters and mimesis, or Visual and aural materials and mimesis. The categories were organized by the instructor because students had no experience analyzing a literary work with mimesis.

As a step 3, each group was supposed to produce their own presentation by analyzing Wuthering Heights and other films (their own selected ones) in the perspective of mimesis. The members of each group selected their own title through group talking. Outside of the classroom, group members exchanged their knowledge and decided their roles through Kakao-Talk for their final outcomes. During the presentation, students assessed other group performances as well as self-reviewed themselves. Last, the participants were required to write essays with specific topics such as Family conflicts, Love and marriage, and Temperature of love during the course. Figure 3 explains the summary of an H-STEAM process and how it can fabricate the attributes of various fields.

FIGURE 3

The Process of H-STEAM
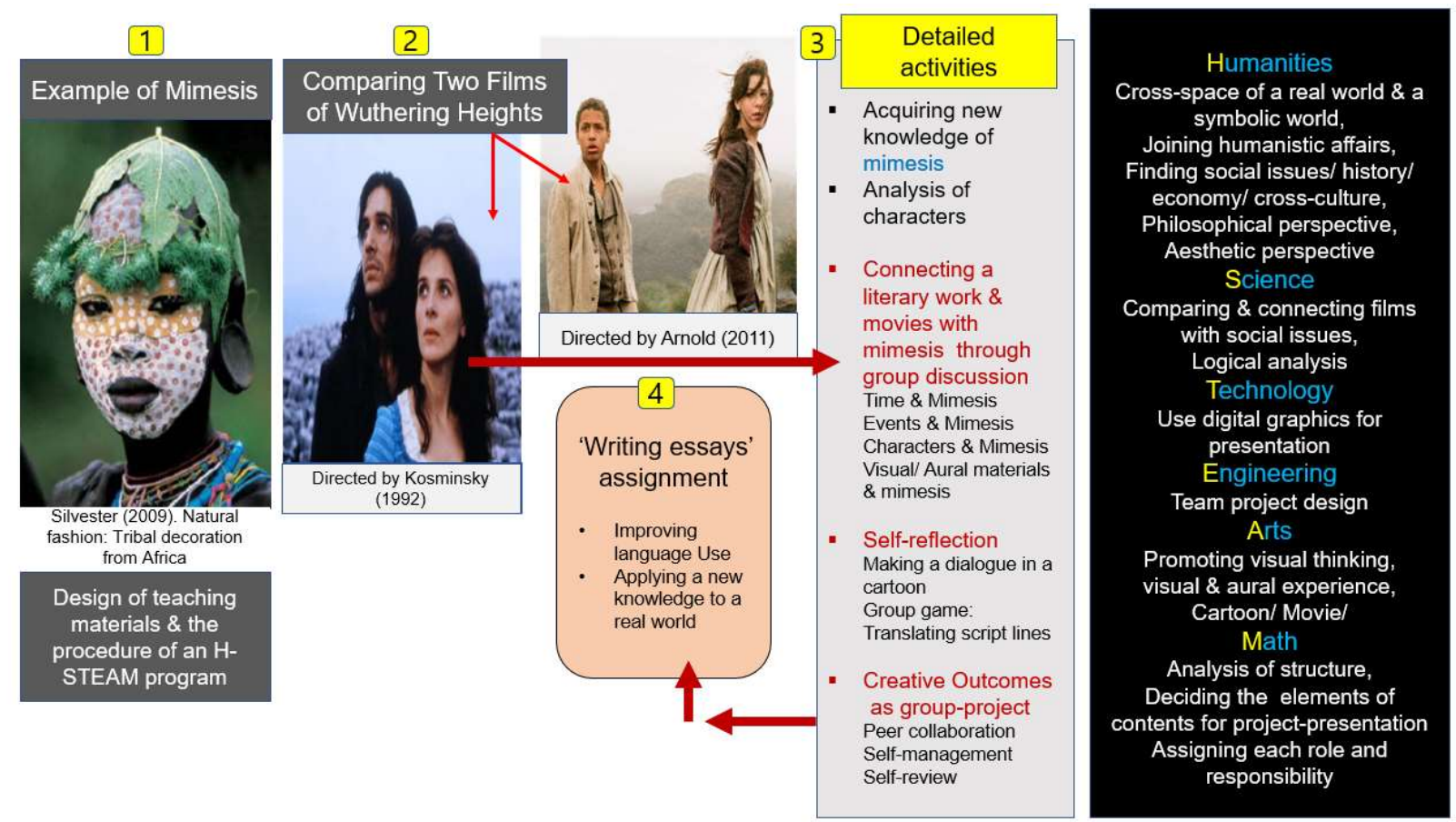

\section{2) The Structure of PBL for an Effective H-STEAM}

Table 3 shows the details of weekly activities of PBL in H-STEAM, which were designed to stimulate 'collaborative learning' through inquiry or communication process and 'conceptual learning' of academic knowledge including linguistic practice. For instance, first, for building conceptual knowledge, a teacher's scaffolding on how to deliver the concept of mimesis was considered carefully. Figure 4 describes the example of the concept of mimesis applied to a mimetic architecture with the title, 'unfamiliar time, familiar space' (Lienhard, n.d.). Learners compared two pictures and formulated inference, which can help them collect appropriate information on how they should produce a digital technology combined group project. Second, to prepare team-presentation, face-to face discussion and KakaoTalk based online discussions were conducted as seen in Figure 4. In the chatting room, one student suggested the possibility that the author (Emily Brontë) might reflect her own life into the characters in Wuthering 
Heights in that her hometown was Howard. They checked how properly the information was collected. Even at night, they talked about whether the arrangement of PowerPoint would be appropriate. They seemed to be responsible for their roles. The process can develop their collaboration and conversation skills, leading to powerful learning by promoting learner-centric learning environment. In addition, a member suggested distributing a summary about the movie they selected in order to help the audience understand the storyline effectively in a limited time. Therefore, they showed caring for others, and an effort to make their best outcome. In a STEAM framework, students can learn how to ask a question, how to learn and how to create as well as concept learning (Kolmos \& Holgard, 2007). So, the use of PBL can promote the process of H-STEAM.

TABLE 3

The Syllabus of PBL-Based Class

\begin{tabular}{|c|c|c|}
\hline Week & Class & Learning Contents \& Objectives. \\
\hline $1^{\text {st }}$ & $\begin{array}{l}\text { Guess what YouTube says! } \\
\text { - Providing situations }\end{array}$ & $\begin{array}{l}\text { Introduction of the class. Pre-test. Appreciating Wuthering Heights (WH), } \\
\text { Grouping, Generating ideas, \& Aesthetic touch }\end{array}$ \\
\hline $2^{\text {nd }}$ & $\begin{array}{l}\text { Understand WH: Theme-based } \\
\text { YouTubes \& a Summary Use }\end{array}$ & $\begin{array}{l}\text { Delivering a YouTube clip via KakaoTalk. Emotional touch through visual } \\
\text { materials. Electronic summary plot }\end{array}$ \\
\hline $3^{\text {rd }}$ & What is Mimesis? & Creating knowledge-building / conceptual learning \\
\hline $4^{\text {th }}$ & $\begin{array}{l}\text { Find 'mimesis' in the story of } \\
\text { WH: Analyzing \& Connecting }\end{array}$ & $\begin{array}{l}\text { Peer collaboration. Understanding \& caring for others by comparing peers' ideas } \\
\text { to mine. Analysis of times, structures, events, human relationships, desire \& } \\
\text { revenge }\end{array}$ \\
\hline $5^{\text {th }}$ & $\begin{array}{l}\text { Figure out the rhetorical } \\
\text { description in WH: Collocation }\end{array}$ & $\begin{array}{l}\text { Activating language learning with collocational knowledge. Understanding the } \\
\text { structures \& the meanings of sentences in main dialogues }\end{array}$ \\
\hline $6^{\text {th }}$ & $\begin{array}{l}\text { Make a cartoon story } \\
\text { describing a specific scene! }\end{array}$ & $\begin{array}{l}\text { Recalling WH \& Creating a story. Experiencing creativity. Practice of language } \\
\text { performance through making sentences }\end{array}$ \\
\hline $7^{\text {th }}$ & $\begin{array}{l}\text { A Card Game: Interpreting } \\
\text { characters' lines of a WH } \\
\text { adaptation with peers }\end{array}$ & $\begin{array}{l}\text { Improving peer collaboration, problem-solving ability \& the ability to judge } \\
\text { situations. Appreciating characters' dialogues. Balance mother tongue and a target } \\
\text { language through translation of dialogues. Recognition of verbal language patterns }\end{array}$ \\
\hline $8^{\text {th }}$ & Discussion \& Writing: & Sharing ideas on Family conflicts. / Love \& Marriage for extended deep thoughts \\
\hline $9^{\text {th }}$ & $\begin{array}{l}\text { Talk \& Write } \\
\text { - Topic-based discussion }\end{array}$ & Finding problems \& solutions. Expressing opinions on Temperature of Love \\
\hline $10^{\text {th }}$ & $\begin{array}{l}\text { The discussion on a creative } \\
\text { design for group presentation in } \\
\text { class \& KakaoTalk-mediated } \\
\text { discussion }\end{array}$ & $\begin{array}{l}\text { Selecting a topic. Promoting peer collaboration \& communication skills for } \\
\text { creative ideas, Deciding members' roles, Analysis of similarities \& differences, } \\
\text { Self-directed learning. Selecting other resources to portray mimesis }\end{array}$ \\
\hline $11^{\text {th }}$ & $\begin{array}{l}\text { Group-presentation through } \\
\text { Digital storytelling / Evaluation }\end{array}$ & $\begin{array}{l}\text { Creating a learner-centric digital technology-combined project with the analysis of } \\
\text { WH and other sources. Post-survey for self-assessment \& peer assessment }\end{array}$ \\
\hline $12^{\text {th }}$ & Evaluation & Post-test \\
\hline
\end{tabular}

FIGURE 4

The Integration of Collaborative and Conceptual Learning

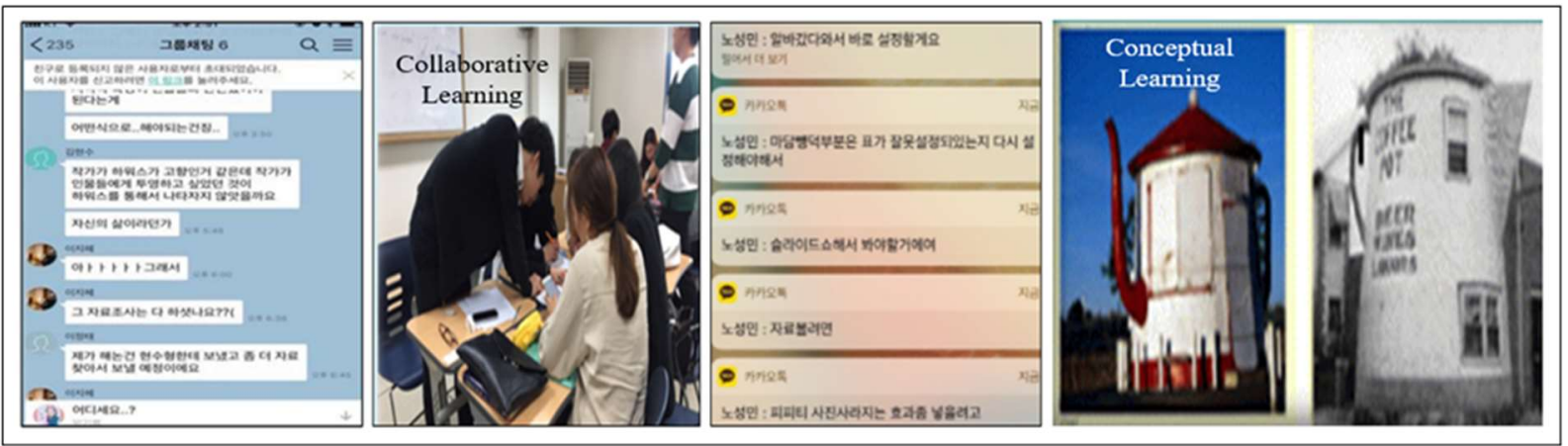

Third, among activities to open a venue for multidisciplinary learning as seen in the weekly PBL list, they participated in linguistic practice as seen in Table 4. First, as an activity to practice language skills in the classroom, students participated in 'a card game'; After drawing lots from a sentence-box which their teacher prepared, learners found the characters' lines, explained the specific situation when a character used the sentence, and translated the 
lines in Korean. Learners could get an opportunity to improve their understanding of the target language and mother tongue, which can be considered as the characteristics of deep learning-oriented H-STEAM (Cho, 2018). Linguistic communication skills with verbal language can be achieved through the movie. The following situations (1 to 3$)$ are the excerpts of activity material 1 . On activity material 2 , learners also made a dialogue according to the cartoon, through which learners could express their creative thinking and reflect the story again. Here, a learner's sentence includes the grammatical correction in brackets as seen in Excerpt of Dialogue 1.

\section{TABLE 4}

Linguistic Practice, Self-Reflection, and Creativity Experience in PBL

The interpretation of storylines through group game
Situation \#1: Nelly's speaking to Heathcliff when taking him to the mirror.
"Well, I say, who is this handsome young squire?"
[응 내가 말해볼게. 이 잘생긴 젊 은 자네 는 누구인가?]
Situation \#2: Earnshaw,s words when Hindley was leaving for school.
"You, be sure to come back from school, a gentleman".
[너는 반드시 학교에서 신사가 되어 돌아올거야.]
Situation \#3: Heathcliff said this when Catherine came back to Wuthering
Heights after healing her injury in Thrushcross Grange.
"You were so close these past months. Why did you never come and see me?"
[너희는 지난 한 달 동안 너무 친해졌어. 왜 넌 나를 보러오지 않았어?]
$\quad$ Creativity through cartoon
<Excerpt of Dialogue 1>
Man 1: If you don't get rid of him, I can't love you.
Woman 1: Sure, I am right now (getting) rid (of) him.
<Excerpt of Dialogue 2>
Man 2: I'm trying to avenge my wife on Cathy's wedding.
Woman 2: Ask Heathcliff not to seek revenge.
Man 3: Edgar and Cathy fight.
Ghost Woman: I'm dissatisfied with Heathcliff.

\section{RESULTS}

\section{The Effect of H-STEAM on Learners' Language Performance}

This study extracted the high-ranked words from the script (Total Token: 11200, Total Type: 1705). The testing questions were based on the collocation using get (Rank 186, 7 questions), keep (Rank 202, 5 questions), take (Rank 111, 1 question), have (Rank 15, 9 questions), make (Rank 145, 4 questions) and do (Rank 46, 4 questions) (see Appendix 2). The questions contained a combination of verb and noun such as do my own business, make the bed, make a real difference, keep company, do the cooking and ironing... etc. Table 5 indicates that an H-STEAM model can contribute statistically to the improvement of EFL learners' language proficiency $(t=2.774, p=.007<.05)$. As collocation can be used mainly in an everyday conversation (Cornell, 1985), it can expose learners to an authentic situation. The learners could be familiar with it while reflecting the specific situation of a dialogue. Therefore, given the pattern of verb and noun frequently, learners could remember it more easily as one block. Table 5 shows the mean $(M)$ and standard deviation $(S D)$ of the tests. Here, the correlation coefficient $(r=.821, p=.000)$ explains a strong tendency that the participants who get high values in the pretest can receive high values in the posttest (Park, Sin, Lee, Hwang, \& Lee, 2012). When considering that although the subjects used in a pretest and a posttest are the same sample, a paired $t$-test always does not show high correlation, this result is statistically significant.

Further, to closely explore the amount of difference of language proficiency between students, the subjects were categorized into 3 levels according to the pretest score after considering descriptive statistics $(M=14.57, S D=3.75$, Median =14, Min =6, Max = 25); Low Group (Min to 12), Middle Group (13 through 19), and High Group (20 through Max). To understand the statistical difference of each group, a one-way ANOVA was performed. Table 6 shows a significant mean change of each group $(F=47.968, p=.000)$. A post hoc test (Scheffé) for multiple 
comparisons verified a significant pairwise difference between groups: Low-Middle $=-3.114^{*}$, Middle-High $=-6.038^{*}$, and High-Low $=9.152 *(p=.000)$. Within groups, the mean change (pre: $10.57<$ post: 12.35$)$ of the Low Group was comparatively large. So, those with low scores in the pretest are expected to improve their collocational knowledge after the experiment as well.

TABLE 5

The Change of Language Proficiency

\begin{tabular}{cccc}
\hline Pre & Post & $t$ & $p$ \\
$M \pm S D$ & $M \pm S D$ & 2.774 & .007 \\
\hline $14.57 \pm 3.75$ & $15.31 \pm 3.77$ & \\
\hline
\end{tabular}

TABLE 6

The Change of Language Proficiency by Groups

\begin{tabular}{cccccc}
\hline Level & Low $(n=23)$ & Middle $(n=39)$ & High $(n=10)$ & $F$ & $p$ \\
& $M \pm S D$ & $M \pm S D$ & $M \pm S D$ & & \\
\hline Post-test & $12.35 \pm 1.968$ & $15.46 \pm 2.459$ & $21.50 \pm 3.4401$ & 47.968 & .000 \\
Pre-test & $10.57 \pm 1.532$ & $15.50 \pm 1.743$ & $22.14 \pm 1.676$ & & \\
\hline
\end{tabular}

Figure 5 displays the frequency of the pretest and the posttest score. The overall frequency rate of the middle part is regular like 7, 7, 7, 8, or 7 ( $n$ of students) in the posttest while the pretest shows a more irregular frequency rate (e.g., 8, 4, 9, 5). Figure 6 portrays the range of each group as blue smoke (all sampling - gray smoke). The blue smoke of each level looks wider in the posttest than in the pretest. Particularly, Level 2 (Middle Group) takes more space. With the findings, it is assumed that learners' individual score difference is not drastic and the gap can become narrow at least.

\section{FIGURE 5}

The Frequency Rate of Pre-Test and Post-Test Score
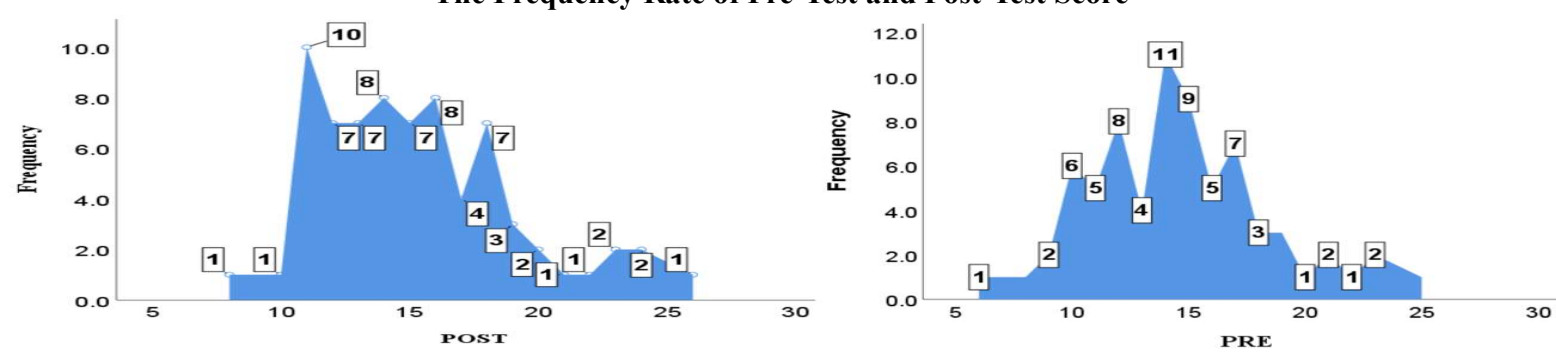

FIGURE 6

The Change of Pre-Test and Post-Test by Groups
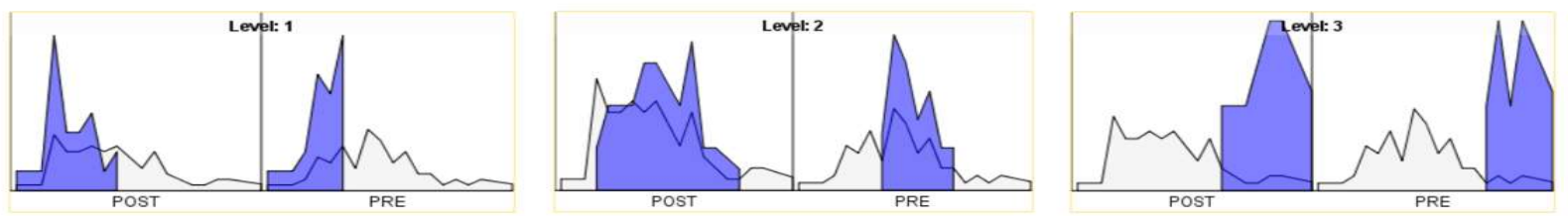

The contents of SA and PA are based on the features of deep learning with $M$ and $S D$ (Table $8 \& 10$ ). Here, the figure of positive answer (\%) indicates the sum of $S A$ (strongly agree) and A (agree). As shown in Table 7, while selfevaluating learning attitude during the experiment, learners adopted peers' opinions actively with openness $(86.1 \%$, SA4), expressed their thoughts as active learners (73.6\%, SA2), and encouraged peers with each other (76.3\%, SA5). With this process, they were built a social relationship, where the group discussion for digging deeper thoughts can improve communication skills and caring (Baek et al., 2012). They reported they did their best in completing their responsibility $(81.9 \%$, SA3) with positive involvement in group presentation $(76.4 \%$, SA1). They could experience self-direction to investigate information as a problem-solving effort $(79.2 \%$, SA6). 
TABLE 7

The Distribution of SA

\begin{tabular}{cccccc}
\hline Items Scale & SA & A & N & D & SD \\
\hline SA1 & $31(43.1 \%)$ & $24(33.3 \%)$ & $15(20.8 \%)$ & $2(2.8 \%)$ & $0(0.0 \%)$ \\
SA2 & $22(30.5 \%)$ & $31(43.1 \%)$ & $17(23.6 \%)$ & $2(2.8 \%)$ & $0(0.0 \%)$ \\
SA3 & $33(45.8 \%)$ & $26(36.1 \%)$ & $12(16.7 \%)$ & $1(1.4 \%)$ & $0(0.0 \%)$ \\
SA4 & $36(50.0 \%)$ & $26(36.1 \%)$ & $9(12.5 \%)$ & $1(1.4 \%)$ & $0(0.0 \%)$ \\
SA5 & $33(45.8 \%)$ & $22(30.5 \%)$ & $12(16.7 \%)$ & $4(5.6 \%)$ & $1(1.4 \%)$ \\
SA6 & $29(40.3 \%)$ & $28(38.9 \%)$ & $14(19.4 \%)$ & $1(1.4 \%)$ & $0(0.0 \%)$ \\
\hline
\end{tabular}

TABLE 8

Self-Assessment of PBL

\begin{tabular}{cllcc}
\hline Items & The aspects of deep learning & Contents of SA & $M$ & $S D$ \\
\hline SA1 & Involvement & Participating in group presentation & 4.17 & .86 \\
SA2 & Generating ideas & Expressing my thoughts & 4.01 & .82 \\
SA3 & Responsibility & Doing my best for my responsibility & 4.25 & .84 \\
SA4 & Openness & Adopting peers' opinions actively & 4.35 & .76 \\
SA5 & Caring & Praising and encouraging members' opinions & 4.14 & .99 \\
SA6 & Self-direction & Searching for project related information \& self-reviewing & 4.18 & .79 \\
& & the findings & & \\
\hline
\end{tabular}

Table 10 shows PA based on deep learning. As seen in Table 9, group members' satisfaction with their roles (73.6\%, PA2) indicates they could build up the learning environment to share academic mindsets (76.4\%, PA3). The strong emotion that they belong to a community with the same goal could formulate the learning process as a social activity, through which they could practice problem-solving ability (Huberman et al., 2014). They also showed community caring by encouraging passive learners $(70.8 \%$, PA5). Peers' feedback was useful to understand the knowledge content (77.8\%, PA4). It developed sympathy and harmony between different ideas (61.1.\%, PA6), enhancing communication and collaborative skills (69.4\%, PA7). Incorporating new ideas with their own experiences, learners could build practical knowledge and produce a creative presentation (76.4\%, PA1). Therefore, peer assessment can help design a frame to activate collaborative regulatory learning and conceptual knowledge learning (Linse, 2016).

TABLE 9

The Distribution of PA

\begin{tabular}{cccccc}
\hline Items Scale & SA & $\mathrm{A}$ & $\mathrm{N}$ & $\mathrm{D}$ & $\mathrm{SD}$ \\
\hline PA1 & $30(41.7 \%)$ & $25(34.7 \%)$ & $14(19.4 \%)$ & $3(4.25 \%)$ & $0(0.0 \%)$ \\
PA2 & $28(38.9 \%)$ & $25(34.7 \%)$ & $14(19.4 \%)$ & $5(6.9 \%)$ & $0(0.0 \%)$ \\
PA3 & $30(41.7 \%)$ & $25(34.7 \%)$ & $13(18.1 \%)$ & $3(4.2 \%)$ & $1(1.4 \%)$ \\
PA4 & $28(38.9 \%)$ & $28(38.9 \%)$ & $12(18.1 \%)$ & $4(5.6 \%)$ & $0(0.0 \%)$ \\
PA5 & $23(31.9 \%)$ & $28(38.9 \%)$ & $16(22.2 \%)$ & $5(6.9 \%)$ & $0(0.0 \%)$ \\
PA6 & $20(27.8 \%)$ & $24(33.3 \%)$ & $23(31.9 \%)$ & $5(6.9 \%)$ & $0(0.0 \%)$ \\
PA7 & $14(19.4 \%)$ & $26(36.1 \%)$ & $24(33.3 \%)$ & $8(11.1 \%)$ & $0(0.0 \%)$ \\
\hline
\end{tabular}

TABLE 10

Peer Assessment of PBL

\begin{tabular}{|c|c|c|c|c|}
\hline Items & The aspects of deep learning & Contents of PA & $M$ & $S D$ \\
\hline PA1 & Creative outcomes & The usefulness of peers' opinions on convergence & 4.14 & .877 \\
\hline PA2 & Role assignment \& Satisfaction & Peers' satisfaction with group-project based role assignment & 4.06 & .933 \\
\hline PA3 & Building academic mindsets & $\begin{array}{l}\text { Playing their parts with problem solving effort for a community } \\
\text { goal }\end{array}$ & 4.11 & .943 \\
\hline PA4 & Conceptual knowledge & The usefulness of peers' feedback on learning concept & 4.11 & .89 \\
\hline PA5 & Community caring & Peers' caring for passive members & 3.96 & .91 \\
\hline PA6 & Sympathy \& Harmony & Understanding members \& finding an acceptable solution & 3.82 & .92 \\
\hline PA7 & $\begin{array}{l}\text { Communication \& } \\
\text { Collaboration skills }\end{array}$ & $\begin{array}{l}\text { The usefulness of collaboration-centric project \& the } \\
\text { development of communication skills }\end{array}$ & 3.64 & .92 \\
\hline
\end{tabular}


Interestingly, the mean scores of PA5, PA6, and PA7 above were under 4 points comparatively. As a possible reason, it was observed that a few students had difficulty in social interaction. For instance, the teams with too introverted or self-assertive members in an unfamiliar classroom seemed to spend more energy in collaboration. For PA7, the lack of learners' language proficiency might be another reason. So, how to form groups should be considered carefully in a further study. Plus, it was surprising that the students seemed rigorous and serious when evaluating peers. The experience can lead to professionality and contribute to the growth of the learners' perception (Miller, 2014).

As SA and PA are reciprocal, the convergent evaluation of SA and PA can release the key elements between them, which can be critical in designing an H-STEAM model. Table 11 shows the correlation of SA and PA $\left(r=.413^{* *}\right)$. Among SA items, SA4 and SA5 have a positive relationship with PA items. The correlations are ranged from $(r=$ $\left.0.273^{*}\right)$ to $\left(r=0.576^{* *}\right)$. PA5, SA4, and SA5 show more significant correlations comparatively (PA5 \& SA4; $r=$ $0.576^{* *}$, PA5 \& SA $\left.5 ; r=0.526^{* *}\right)$.

TABLE 11

The Correlation of SA and PA

\begin{tabular}{|c|c|c|c|c|c|c|c|}
\hline & PA1 & PA2 & PA3 & PA4 & PA5 & PA6 & PA7 \\
\hline \multirow[t]{2}{*}{ SA1 } & -.050 & -.047 & .029 & .143 & .208 & .270 & .131 \\
\hline & $(.670)$ & $(.695)$ & $(.808)$ & $(.230)$ & $(.080)$ & $(.022)$ & $(.274)$ \\
\hline \multirow[t]{2}{*}{ SA2 } & -.022 & .073 & .127 & .135 & $.343 * *$ & $.341 * *$ & .100 \\
\hline & $(.851)$ & $(.541)$ & $(.290)$ & $(.257)$ & $(.003)$ & $(.003)$ & $(.401)$ \\
\hline \multirow[t]{2}{*}{ SA3 } & .067 & .127 & .250 & .172 & $292 *$ & $260 *$ & .173 \\
\hline & $(.574)$ & $(.289)$ & $(.034)$ & $(.148)$ & $(.013)$ & $(.027)$ & $(.145)$ \\
\hline \multirow[t]{2}{*}{ SA4 } & $.437 * *$ & $.273^{*}$ & $.421 * *$ & $.408 * *$ & $.576 * *$ & $.435 * *$ & $.324 * *$ \\
\hline & $(.000)$ & $(.020)$ & $(.000)$ & $(.000)$ & $(.000)$ & $(.000)$ & $(.005)$ \\
\hline \multirow[t]{2}{*}{ SA5 } & $.467 * *$ & $329 * *$ & $.454 * *$ & $.421 * *$ & $.526^{* *}$ & $.462 * *$ & $.475 * *$ \\
\hline & $(.000)$ & $(.005)$ & $(.000)$ & $(.000)$ & $(.000)$ & $(.000)$ & $(.000)$ \\
\hline \multirow[t]{2}{*}{ SA6 } & .004 & .081 & .142 & .152 & $.323 * *$ & $.333 * *$ & .033 \\
\hline & $(.974)$ & $(.496)$ & $(.233)$ & $(.202)$ & $(.006)$ & $(.004)$ & $(.786)$ \\
\hline
\end{tabular}

$* * p=0.01, * p=0.05$

FIGURE 7

The Effect of Openness (SA4) and Caring (SA5) on PA

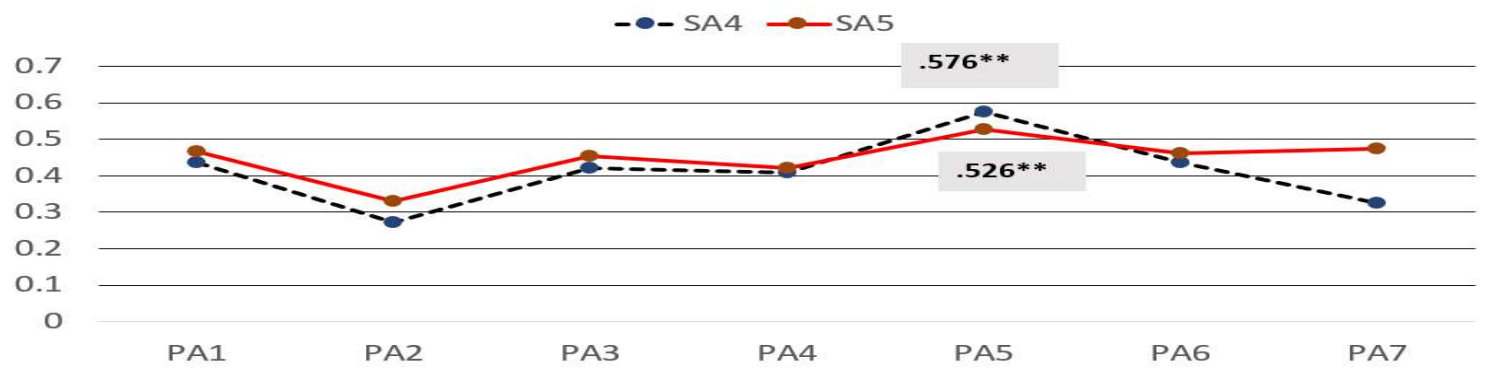

Figure 7 shows the general change of S4 and SA5 in the perspective of the relationship with PA. SA4 (Openness) has more positive relationship with PA5 (Community caring). It means that the more efforts learners put to listen to peers' ideas without prejudice, the more a team could cooperate to complete a group project (Cress \& Kimmerle, 2008). With the process, students also can practice sophisticated language to deliver their ideas logically. Therefore, the learning process to generate deep learning in multidisciplinary departments can be based on the creation of the harmonious relationship between self and others.

\section{The Outcomes of Learner-Centric Problem-Solving}

\section{1) The Efficacy of H-STEAM}

In fact, on the open-ended questions on the experience of H-STEAM, students expressed they felt so confused at first when hearing of the term, mimesis, but they found themselves familiar with the integration analysis. At the end 
of the semester, they could acquire new knowledge through an H-STEAM model. They described their experience with the words such as 'freshness', 'strong impression', 'challenging experience', 'challenging project' 'rewarding class', or 'fun'. Students also reported their experience such as "Through the old movie, I can understand the value of classic literature and the combination of the new and the old." "I was surprised to appreciate the movie in the new perspective." "I could follow the class course without difficulty due to my teacher's enthusiastic scaffolding to design H-STEAM." However, some expressed negative feeling like that due to many tasks, they were always busy doing something. There were some worries on whether they could cause a problem to their team, and the pressure of writing an essay in English with a lack of grammatical structure. Table 12 summarized learners' responses on H-STEAM.

TABLE 12

Learners' Responses

\begin{tabular}{|c|c|c|}
\hline Questions & Positive responses & Negative responses \\
\hline $\begin{array}{c}\text { Feeling } \\
\text { after H-STEAM class }\end{array}$ & $\begin{array}{l}\text { New experience \& freshness } \\
\text { Challenging \& interesting project } \\
\text { Rewarding class \& fun } \\
\text { Finding the new value of classic literature } \\
\text { Comparison analysis practice } \\
\text { Recognizing the role of mimesis \& inducing } \\
\text { similarity from different movies }\end{array}$ & $\begin{array}{l}\text { Having many tasks } \\
\text { According to group members, the quality of the } \\
\text { outcome of a student-centric project can be } \\
\text { different. } \\
\text { With a lack of grammar, it was a hard class to me. } \\
\text { The difficulty of writing essay }\end{array}$ \\
\hline
\end{tabular}

\section{2) Learner-Centric Deep Thoughts}

Table 13 shows the development of students' analysis ability in the perspective of mimesis. Learners connected scene, foreshadowing, supernaturality, emotion and allusion with mimesis. They could recognize that a gothic setting was shown through dark images, violent characters and supernaturality of Catherine's ghost. They tried to understand what would happen when the faces of Catherine and young Cathy were overlapped. Even a student described the historical implication of fashion as the outcome of their group project. Therefore, the analyzing activity can develop learners' cognition as well (Cress \& Kimmerle, 2008).

TABLE 13

Learner-Centric Analysis for Deeper Thoughts

\begin{tabular}{ll}
\hline Scene \& Mimesis & $\begin{array}{l}\text { Light \& Darkness: Showing climax of conflict by assigning a dark image to Heathcliff and light } \\
\text { image to Catherine. }\end{array}$ \\
\hline Foreshadowing & $\begin{array}{l}\text { Catherine's facial change overlapped with young Cathy, Catherine's daughter, implicates that } \\
\text { Heathcliff can't free himself from the restraints of Catherine. }\end{array}$ \\
\hline $\begin{array}{l}\text { Supernaturality \& } \\
\text { Mimesis }\end{array}$ & Catherine's ghost portrays Heathcliff's preoccupation that he is protected by the soul of Catherine. \\
\hline Emotion \& Mimesis & $\begin{array}{l}\text { A dark and vast moor in the daytime represents Heathcliff's forlorn emotion and loneliness when } \\
\text { spotting that Edgar and Catherine got cozy. }\end{array}$ \\
\hline Allusion & $\begin{array}{l}\text { The scene that Hindley is wavering a glass and closing the door in an alcoholic haze implies } \\
\text { Hindley's wreck. }\end{array}$ \\
\hline Fashion \& Mimesis & $\begin{array}{l}\text { The 19th Victorian fashion was the symbol of the Bourgeois under patriarchy. It was an indicator of } \\
\text { social status. Clothing reflects a process of the formation of attitudes and images of men \& women. }\end{array}$ \\
\hline
\end{tabular}

Figure 8 shows the result of learner-centric group projects. One group explained Wuthering Heights in the perspective of weather and mimesis. Clear days identify the fact that Catherine was always with Heathcliff even when Heathcliff was treated with contempt because of the social position of an orphan. However, rain in the daytime implies the change of love between the couple. Stormy days imply pain and sadness as well as their desire to keep their true love in unexpected situations. After Catherine's death, rain represents Heathcliff's deep suffering. In comparison with the movie, New World (Korean; Sinsegye) (Yim, 2014), the group introduced 'circumlocution', the way to express a situation vaguely or paradoxically with unnecessary words instead of using an exact word or expression directly. For instance, Joong-gu, (a character in New World) who sensed his death, said "it's a nice day" when finding rolling dark clouds. It reveals his fortitude and melancholy before dying. 
FIGURE 8

A Sample of Leaner-Centric Project

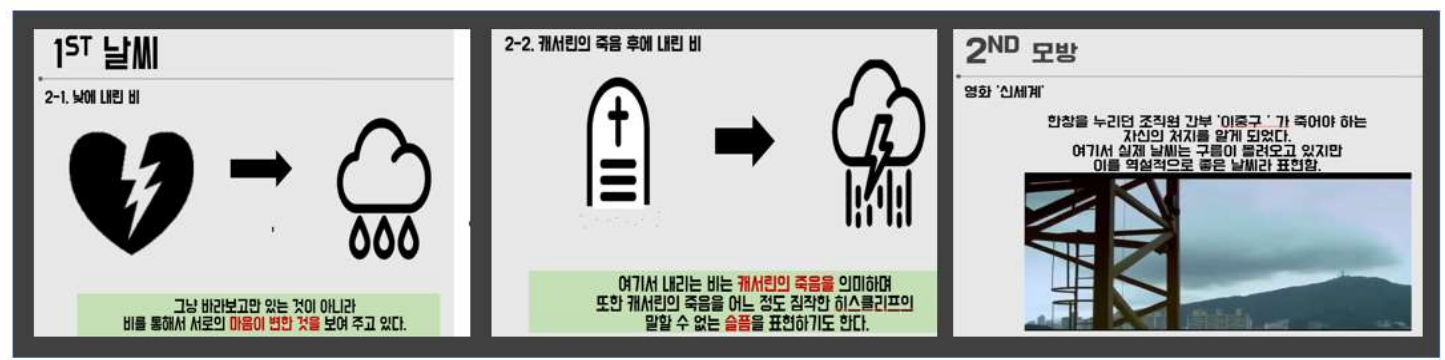

Another team compared Wuthering Heights with the movie Scarlet Innocence (Korean; Madam, BBangduck, Yim, 2014). The two movies have revenge in common; Heathcliff becomes revengeful against Hindley and Edgar as he was ill-treated by Hindley and Catherine married Edgar, while Deok-ee's revenge was against Hak-kyu because she was abandoned from Hak-kyu. Like this, the team analyzed the relationship between characters.

As time went by, the participants improved their analysis ability. They reflected 'problem-solving effort' in their own life while applying new knowledge to novel situations. For instance, when provided with the title of family conflicts, some compared the conflict between Heathcliff and Hindley in Wuthering Heights with that in a Korean traditional fairy tale, Kongjwi and Patjwi. A student evaluated that the climax of the conflict was caused when Catherine selected Edgar's social status.

S1: I think solving a family problem is not difficult. The most important thing about solving family problems is understanding each other...

S2: Family conflict can cause annoyance, but a better solution can come from dialogue. Dialogue is very important as we can understand each other's thoughts through dialogue ...

S3: It is like the story of Kongjwi and Patjwi. Hindley bothers Heathcliff and makes him suffer like Kongjwi's stepmother. I thought every conflict was from Heathcliff. If he had not wanted revenge, there wouldn't have been conflicts in the movie ...

S4: Catherine did not choose Heathcliff but eventually chose the rich and honorable Edgar to keep her status ...

While analyzing Wuthering Heights, students explored the way to overcome conflicts. Some insisted to accept individuals' unique personalities. Others extended their own view from family conflicts (the tile of writing) to a social issue that is related to marginalized neighbors and multicultural families. Further, a student listed the method to solve family conflict through the education at table: (a) Prepare the meals together, eat together and clean together, (b) Eat together more than twice a week, (c) Turn off the TV and use cellphone after a meal, (d) Eat slowly with talking, (e) Use questions like "how should we do to make something good?" (f) Sympathize and praise instead of telling something negative...etc. Accordingly, PBL in an H-STEAM platform provided the learners with authenticity to achieve deep thoughts about their real life.

\section{CONCLUSION AND IMPLICATIONS}

This study explored how an H-STEAM model integrated with literature, philosophy, and language could contribute to learners' deep thoughts and linguistic development. The objective of this empirical research was also to activate learners' participation and self-reflection through student-based assessment and to verify what elements were considered more workable when fabricating PBL in H-STEAM. This study emphasizes the significance of an HSTEAM model in the following four aspects: (a) Promoting linguistic development, (b) An accelerator of deep learning, (c) The creation of conceptual learning and collaborative learning through PBL, (d) Activating 'studentcentric learning' through student-based assessment (SA and PA). 
First, in the linguistic aspect, students could acquire collocational knowledge through the patterns of verbal language. Although the difference of mean score was not high between the tests, a paired $t$-test showed the potentials to use H-STEAM for language proficiency practice $(t=2.774, p=.007<.05)$. The mean change by groups $(F=$ $47.968, p=.000$ ) also was found through a one-way ANOVA. Particularly, the mean difference (pre: $10.57<$ post: 12.35) for lower leveled learners was comparatively noticeable. For a possible reason, although their language proficiency was low, the responsibility that they should be engaged in PBL step by step and a sense of belonging from community caring might bring out 'involvement'. Second, in the aspect of deep learning, the H-STEAM model based on the convergence of a literary work, Wuthering Heights, a philosophical framework, mimesis, and aesthetic features of media could stimulate learners' thinking skills. In detail, through visual materials, the group activities for communication and collaboration skills, and writing for digging deep thoughts, it could improve learners' critical thinking skills and creativity. With stimulating learners' visual thinking and cognition (Cress \& Kimmerle, 2008), both sensing the implication of the scenes and finding mimesis can provide learners with an opportunity to view Wuthering Heights from a new perspective. Accordingly, deep learning can be activated naturally in an H-STEAM environment, where learner' previous knowledge can be applied to their real-world experience and virtual scenarios. Third, PBL-based discussion and learners' inquiry could contribute to enhancing learners' participation in authenticity, enlarging the depth of knowledge, and reviewing their acquired knowledge (Miller \& Krajcik, 2019). PBL can provide members with a shared learning goal and assign them individual roles and create a learning environment where all the members participate in learning. Four, students-based assessment through SA and PA $\left(r=.413^{* *}, p=.000\right)$ played a crucial role in evaluating the efficacy of PBL to induce learners' participation and deep learning in H-STEAM. They themselves could self-review their own learning attitude and knowledge acquisition as well as team members' efforts as evaluators while experiencing critical thinking-oriented convergence and collaborative learning beyond a single department. Particularly, among the items of SA and PA, PBL required the co-operation $\left(r=.576^{* *}, p=.000\right)$ of learners' openness (SA4) and community caring (PA5) more than other elements. Sharing and listening to peers' ideas without prejudice could develop an academic mindset by forming a sense of belonging to a community with the same goal. Accordingly, humanities can amplify the learning objectives of generating holistic education which enables spiritual, emotional, and physical development by reconsidering the social relation between self and others through community caring. In addition, student-based assessment in PBL can lead to long-term memory (Kolmos \& Holgard, 2007; Salmia et al., 2020), which can explain the usefulness of PBL in H-STEAM. However, large samples in further studies can make solid generation through statistical results. Further, in a PBL experiment, learners' affective domain such as visual thinking skills, challenge, or achievement can be studied to verify the effectiveness of H-STEAM.

In this study, the H-STEAM model emphasizes the balance of teachers' careful instruction and learners' active involvement. First, on the part of teachers, the creative and integrative teaching materials to promote learners' thinking practice and conceptual knowledge should be fabricated. It shows the significance of teachers' role $(\mathrm{Gu}$, 2021). In fact, a philosophical analysis framework such as mimesis required the teacher to spend significant effort in planning the class with conscious awareness about effective STEAM education. Second, in the aspect of learners, the innovative learning method to combine various learning areas can look like a challenge at first. Yet, we should remember that once learners experience something new, the experience can lead to new ideas, developing problemsolving abilities. Consequently, despite the difficulty of the design, this study can be used as an empirical resource to contribute to developing an effective H-STEAM targeting undergraduates as well as high school students and adults for lifetime education. Hopefully, the H-STEAM model may suggest a possibility to solve the current concern that humanities can be used as a temporary device.

\section{REFERENCES}

Alias, M., Masek, A., \& Md Salleh, H. H. (2015). Self, peer and teacher assessment in problem-based learning: Are they in agreements? Procedia - Social and Behavioral Science, 204, 309-317. https://doi.org/10.1016/j.sbspro.2015.08.157

Angel, L. (2016, May 5). Wuthering Heights 1939 (HD) - Queen of my hearts [Video file]. Retrieved from https://www.youtube.com/watch?v=-SHPD2me3i0\#t=5.860001 
Arnold, A. (Director). (2011). Wuthering Heights [Motion picture]. United Kingdom: UK Film Council and HanWay Films.

Baek, Y. S., Park, H. J., Kim, Y. M., Noh, S. G., Park, J. Y., Lee, J. Y., Jeong, J. S., Choi, Y. H., \& Han, H. S. (2012). STEAM education in Korea. Journal of Learner-Centered Curriculum and Instruction, 11(4), 149-171. Retrieved

from https://www.kci.go.kr/kciportal/ci/sereArticleSearch/ciSereArtiOrteView.kci?sereArticleSearchBean.artiId= ART001614968

Baker, E. A. (2017). Apps, iPads, and literacy: Examining the feasibility of speech recognition in a first-grade classroom. Reading Research Quarterly, 52(3), 291-310. https://doi.org/10.1002/rrq.170

Bourdeau, D. T., \& Wood, B. L. (2021). Humanistic STEM: From concept to course. Journal of Humanistic Mathematics, 11(1), 33-53. https://doi.org/10.5642/jhummath.202101.04

Brontë, E. (1996). Wuthering Heights. Retrieved from https://www.gutenberg.org/ebooks/author/405

Bronte, S. (2010, August 29). Wuthering Heights - Kate Bush (1992 clips) [Video file]. Retrieved from https://youtu.be/ShunlG2aRUI

Brumberger, E. R. (2007). Making the strange familiar: A pedagogical exploration of visual thinking. Journal of Business and Technical Communication, 21(4), 376-401. https://doi.org/10.1177/1050651907304021

Cho, Y. K. (2018). Development and effect of H-STEAM centering on secondary education of Korea. International Journal of Advanced Culture Technology, 6(3), 1-11. https://doi.org/10.17703/IJACT2018.6.3.1

Choi, J. H., \& Lee, H. S. (2016). Drama \& film English: A case study of English class as liberal education, converged on literature and theatrical performances for cultivating humanities. The Journal of the Korea Contents, 16(3), 536-545. https://doi.org/10.5392/JKCA.2016.16.03.536

Coombs, D. (2012). Using Ricoeur's mimetic process to examine the identities of struggling adolescent readers. English Teaching: Practice and Critique, 11(1), 82-103. Retrieved from http://files.eric.ed.gov/fulltext/EJ970222.pdf

Cornell, A. (1985). Realistic goals in teaching and learning phrasal verbs. International Review of Applied Linguistics in Language Teaching, 23(4), 269-280. https://doi.org/10.1515/iral.1985.23.1-4.269

Cress, U., \& Kimmerle, J. (2008). A systemic and cognitive view on collaborative knowledge building with wikis. Computer-Supported Collaborative Learning, 3, 105-122. https://doi.org/10.1007/s11412-007-9035-z

David, W. (1991). On Paul Ricoeur: Narrative and interpretation. New York, NY: Routledge.

Ferns, J. (2003). Q. D. Leavis's criticism: The human core. Modern Age, 45(2), 165-173. Retrieved from https://isiorg.b-cdn.net/wp-content/uploads/2014/10/ferns.pdf?x27782

Ford, M. (2008). Five short plays. New York, NY: Oxford University Press.

Gogh, V. V. (1889). The starry night [Image file]. Retrieved from https://commons.wikimedia.org/wiki/File:VanGogh-starry_night_edit.jpg

Golonka, E. M., Bowles, A. R., Frank, V. M., Richardson, D. L., \& Freynik, S. (2014). Technologies for foreign language learning: A review of technology types and their effectiveness. Computer Assisted Language Learning, 27(1), 70-105. https://doi.org/10.1080/09588221.2012.700315

$\mathrm{Gu}, \mathrm{F}$. (2021). On deep learning-based synthesis of language training and humanistic education in college English teaching. Open Access Library Journal, 8, e7493. https://doi.org/10.4236/oalib.1107493

Huberman, M., Bitter, C., Anthony, J., \& O’Day, J. (2014). The shape of deeper learning; Strategies, structures, and cultures in deeper learning network high school (Rep. No. 1). New York, NY: The Research Alliance for New York City Schools. Retrieved from https://files.eric.ed.gov/fulltext/ED553360.pdf

Hillyard, S. (2021, April 8). How to integrate STEAM in English language classrooms [Blog post]. Retrieved from https://www.english.com/blog/how-to-integrate-steam-in-english-language-classrooms/

Hong, M. A., Hwang, B. K., \& Choi, J. H. (2012). The development of STEAM education textbook on water pollution. Journal of Environmental Science International, 21(8), 909-929. https://doi.org/10.5322/JES.2012.21.8.909

Housen, A. C. (2002). Aesthetic thought, critical thinking and transfer. Arts and Learning Research, 18(1), 99-132. Retrieved from https://citeseerx.ist.psu.edu/viewdoc/download?doi=10.1.1.467.3752\&rep=rep1\&type=pdf

Jensen, E., \& Nickelsen, L. (2008). Deeper learning: 7 powerful strategies for in-depth and longer-lasting learning. Thousand Oaks, CA: Corwin Press. 
Kang, D. H., Lee, C. M., \& Lee, J. H. (2014). A study on the content analysis of emotional touch in A-STEAM programs. Art Education Review, 52, 1-32. Retrieved from https://www.kci.go.kr/kciportal/ci/sereArticleSearch/ciSereArtiView.kci?sereArticleSearchBean.artiId=ART 001930472

Kim, J. H., Lee, Y. H., Park, W. K., Park, Y. S., Park, H. J., \& Chun, K. H. (2015). The development of a theoretical model of integrated medical humanity curriculum using science, technology, engineering, arts, and mathematics model. Korean Medical Education Review, 17(1), 39-48. https://doi.org/10.17496/kmer.2015.17.1.39

Kim, Y.-S. G., \& Schatschneider, C. (2017). Expanding the developmental models of writing: A direct and indirect effects model of developmental writing (DIEW). Journal of Educational Psychology, 109(1), 35-50. https://doi.org/10.1037/edu0000129

Kolmos, A., \& Holgard, J. E. (2007). Alignment of PBL and assessment. Journal of Engineering Education Washington, 96(4), 1-9. Retrieved from https://vbn.aau.dk/ws/portalfiles/portal/13219824/Alignment_of_PBL_and_Assessment.pdf

Kosminsky, P. (Director). (1992). Wuthering Heights [Motion picture]. UK: Paramount Pictures.

Kwon, H., Park, K., \& Lee, H. (2009). Research trends on the integrative efforts in technology education: Reviews of the relevant journals. Secondary Education Research, 57(1), 245-274. https://doi.org/10.25152/ser.2009.57.1.245

Lathan, J. (2021). Why STEAM is so important to $21^{\text {st }}$ century education [Blog post]. Retrieved from https:/onlinedegrees.sandiego.edu/steam-education-in-schools/

Lee, D. H. (2015). The development and implementation of G-STEAM (geography-centered STEAM education): A lesson on 'renewable energy power plants built in our town'. Journal of the Association of Korean Geographers, $\quad 4(1), \quad 15-34 . \quad$ Retrieved from https://www.kci.go.kr/kciportal/ci/sereArticleSearch/ciSereArtiOrteView.kci?sereArticleSearchBean.artiId= ART002013299

Lee, H. J., \& Lim, C. I. (2012). Peer evaluation in blended team project-based learning: What do students find important? Educational Technology \& Society, 15(4), 214-224. Retrieved from https://www.researchgate.net/publication/286056633_Peer_Evaluation_in_Blended_Team_ProjectBased_Learning_What_Do_Students_Find_Important\#read

Lienhard, J. (n.d.). No. 799 Mimetic architecture [Blog post]. Retrieved from https://www.uh.edu/engines/epi799.htm Linse, R. A. (2016). Team peer evaluation. Retrieved from https://www.schreyerinstitute.psu.edu/pdf/Team_Peer_Evaluation_Examples.pdf

Liu, E. Z. F., Lin, S. S. J., \& Yuan, S. M. (2002). Alternatives to instructor assessment: A case study of comparing self and peer assessment with instructor assessment under a networked innovative assessment procedures. International Journal of Instructional Media, 29(4), 395-404. Retrieved from https://www.researchgate.net/publication/260186633_Alternatives_to_instructor_assessment_A_case_study _of_comparing_self_and_peer_assessment_with_instructor_assessment_under_networked_innovative_asses sment_procedures

Macdonald, B. (2008). Assessment for learning in project-based learning. International Journal of Learning: Annual Review, 14(10), 15-28. https://doi.org/10.18848/1447-9494/CGP/v14i10/45493

Matrix, S., \& Hodson, J. (2014). Teaching with infographics: Practicing new digital competencies and visual literacies. The Journal of Pedagogic Development, 4(2), 17-27. Retrieved from https://uobrep.openrepository.com/bitstream/handle/10547/335892/Teaching-with-Infographics-PracticingNew-Digital-Competencies-and-Visual-Literacies.pdf?sequence=1\&isAllowed $=\mathrm{y}$

McCaffery, S. G. (2008). Mimesis and second language acquisition: A sociocultural perspective. Studies in Second Language Acuqisition, 30(2), 147-167. https://doi.org/10.1017/S0272263108080297

Miller, A. (2014). PBL and STEAM education: A natural fit. Edutopia [Blog post]. Retrieved from https://www.edutopia.org/blog/pbl-and-steam-natural-fit-andrew-miller 
Miller, E. C., \& Krajcik, J. C. (2019). Promoting deep learning through project-based learning: A design problem. Disciplinary and Interdisciplinary Science Education Research, 1(7), 1-10. https://doi.org/10.1186/s43031019-0009-6

Movieclips Coming Soon. (2012, September 27). Wuthering Heights TRAILER. Sundance Movie HD [Video file]. Retrieved from https://www.youtube.com/watch?v=3-b0DBepmgo

Nolan, C. (Director). (2014). Interstellar [Motion picture]. United States: Paramount Pictures.

Park, H. J., Byun, S. Y., Sim, J. H., Baek, Y. S., \& Jeong, J. S. (2016). A study on the current status of STEAM education. Journal of The Korean Association for Science Education, 36(4), 669-679. https://doi.org/10.14697/jkase.2016.36.4.0669

Park, Y. O., Sin, J. Y., Lee, B. I., Hwang, H. S., \& Lee, S. H. (2012). SPSSreul whalyonghan tonggyejaryo bunsuk [Statistical data analysis using SPSS] (2nd ed.). Seoul: Kyungmoonsa.

Pastreich, E. (2018, June 30). New importance of humanities in fourth industrial revolution. The Korea Times. Retrieved from http://www.koreatimes.co.kr/www/opinion/2018/11/723_251400.html

Polman, J. L. (2000). Designing project-based science: Connecting learners through guided inquiry. New York, NY: Teachers College Press.

Price, D. (1996, December). The Project Gutenberg eBook of Wuthering Heights, by Emily Brontë. Retrieved from https://www.gutenberg.org/files/768/768-h/768-h.htm

Salmia, H. S., Thuneberga, H., \& Bogner, F. X. (2020). Is there deep learning on Mars? STEAM education in an inquiry based out-of-school setting. Interactive Learning Environment. https://doi.org/10.1080/10494820.2020.1823856

Schmid, S., \& Bogner, F. (2015). Effects of students' effort scores in a structured inquiry unit on long-term recall abilities of content knowledge. Education Research International. https://doi.org/10.1155/2015/826734

Scott, R. (Director). (2015). The martian [Motion picture]. United States: 20th Century Fox.

Shakespeare, W. (2008). Hamlet. New York, NY: Oxford University Press.

Shelly, M. W. (1818). Frankenstein: Or the modern Prometheus - The 1818 text. London: Oxford University Press.

Silverster, H. (2009). Natural fashion: Tribal decoration from Africa. Melbourne: Thames \& Hudson.

Stoneman, P. (Ed.) (1998). Emily Brontë: Wuthering Heights - A reader's guide to essential criticism. London: Palgrave Macmillan.

Tanrikulu, F. (2020). Students' perceptions about the effects of collaborative digital storytelling on writing skills. Computer Assisted Language Learning. Advance online publication. https://doi.org/10.1080/09588221.2020.1774611

Treffinger, D. J., Young, G. C., Selby, E. C., \& Shepardson, C. (2002). Assessing creativity: A guide for educators. The National Research Center on the Gifted and Talented (NRC GIT). Retrieved from http://files.eric.ed.gov/fulltext/ED505548.pdf

Wachowski, L., \& Wachowski, L. (Directors). (1999). The Matrix [Motion picture]. United States: Warner Brothers.

Warburton, K. (2003). Deep learning and education for sustainability. International Journal of Sustainability in Higher Education, 4(1), 44-56.

Whitman, W. (1865). When I heard the learn'd astronomer. Retrieved from https://static1.squarespace.com/static/5a2a82e0a9db09cbacc8eb55/t/5f9705d62738b804a385e76e/16037329 51833/When+I+Hear+the+Learn\%27d+Asntronomer.pdf

Yang, Y.-T. C., Chen, Y.-C., \& Hung, H.-T. (2020). Digital storytelling as an interdisciplinary project to improve students' English speaking and creative thinking. https://doi.org/10.1080/09588221.2020.1774611

Yim, P. S. (Director). (2014). Scarlet innocence. Seoul: CJ Entertainment. 


\section{APPENDIX 1}

A Post-Survey

A post-survey was based on 5 Likert; Strongly Agree (5 points), Agree (4 points), Neutral (3 points), Disagree (2), Strongly Disagree (1 point).

\begin{tabular}{|c|c|c|c|c|c|c|c|}
\hline \multicolumn{3}{|r|}{ Multiple choice of Questions } & SA & A & $\mathrm{N}$ & $\mathrm{D}$ & SD \\
\hline \multirow{6}{*}{$\begin{array}{l}\text { S } \\
\text { A }\end{array}$} & 1 & I participated in group presentation. & & & & & \\
\hline & 2 & I expressed my thoughts. & & & & & \\
\hline & 3 & I did my best for my responsibility. & & & & & \\
\hline & 4 & I adopted peers' opinions actively. & & & & & \\
\hline & 5 & I praised and encouraged members' opinions. & & & & & \\
\hline & 6 & I searched for project-related information and self-reviewed the findings. & & & & & \\
\hline \multirow{7}{*}{$\begin{array}{l}\mathrm{P} \\
\mathrm{A}\end{array}$} & 7 & I think peers' opinions on converge are useful. & & & & & \\
\hline & 8 & I think peers were satisfied with group-project based role assignment. & & & & & \\
\hline & 9 & I think peers played their parts with problem-solving effort for a community goal. & & & & & \\
\hline & 10 & I think peers' feedback on learning concept were useful. & & & & & \\
\hline & 11 & I think peers tried to care for passive members. & & & & & \\
\hline & 12 & I think peers can understand members and find an acceptable solution. & & & & & \\
\hline & 13 & $\begin{array}{l}\text { I think collaboration-centric project is useful and the communication skills can be } \\
\text { developed through this class. }\end{array}$ & & & & & \\
\hline \multicolumn{8}{|c|}{ Open-ended Questions } \\
\hline & 14 & \multicolumn{6}{|l|}{ Write your experience of classic literature and movie. } \\
\hline & 15 & \multicolumn{6}{|l|}{ Write your feeling when hearing the term of mimesis. } \\
\hline & 16 & \multicolumn{6}{|l|}{ Write your feeling after combining Wuthering Heights and mimesis. } \\
\hline
\end{tabular}

\section{APPENDIX 2}

\section{Sample of a Pre-Test and a Post-Test}

The tests for language Proficiency were based on collational words extracted from Wuthering Heights

*Select a proper word

1. I hope to my own business one day.

(a) do (b) have (c) make

2. Many countries .......... problems with obesity.

(a) do (b) have (c) make

3. It'll be a miracle if I can her alive.

(a) keep (b) get (c) give

4. I'm planning to ....... a holiday in June or July.

(a) do (b) have (c) make

5. I usually ........ the cooking and ironing in our house.

(a) do (b) have (c) make 